Article

\title{
Prepared to Teach for Sustainable Development? Student Teachers' Beliefs in Their Ability to Teach for Sustainable Development
}

\author{
Thomas Dahl 1 D \\ Department of Teacher Education, Norwegian University of Science and Technology, N-7491 Trondheim, \\ Norway; thomas.dahl@ntnu.no
}

Received: 21 January 2019; Accepted: 27 March 2019; Published: 3 April 2019

\begin{abstract}
The importance of embedding education for sustainable development has been emphasised over many years. At the same time, there has been a massive call for initial teacher education to provide all student teachers with the core of professional competences. What is the status of teacher education today in embedding education for sustainable development and how does it relate to the focus on professional competencies in teacher education? A total of 578 student teachers in seven different teacher education programmes in Europe were surveyed, measuring the students' beliefs in their ability to work as teachers, as well as their ability to teach in ways that value sustainability and promote environmentally sound ways of living. The results of the survey show that student teachers feel well prepared to handle many aspects of teacher professionalism, but less prepared to educate for sustainability. The survey also indicates that student teacher training in educating for sustainability is not integrated in their other training and is generally just added on.
\end{abstract}

Keywords: teacher professional competences; education for sustainable development; teacher education; self-efficacy; survey; principal component analysis

\section{Introduction}

What content should be included in teacher education? Traditionally, this education is supposed to give student teachers the knowledge they need to work effectively as teachers. Most teacher education programmes are still divided into three core knowledge sections: content, pedagogical content and general pedagogical [1]. As the knowledge needs to be used in teaching, teacher education also normally includes practical training.

While quality has been traditionally measured by the strength of the different competences among teachers, there is now a trend to see what student teachers are capable of doing as actual teachers. This shift parallels the move from grades to capacities in both school and education policies. One of the strongest and most used theoretical supports for this shift is Albert Bandura's cognitive theory on efficacy [2,3]. With the concept of self-efficacy, Bandura states that the ability to do something is, to a high degree, dependent on the belief a person has in her or his ability. This theory has gained massive empirical support [4-12] and determines several of the questions in the OECD Teaching And Learning International Survey (TALIS), which asks about teachers' efficacy in classroom management, instruction and student engagement $[13,14]$.

In line with this, instead of asking about the competence of student teachers, we should ask the following. What do student teachers feel or think they are capable of or prepared to do? What do they think they can do as teachers?

But what should future teachers be able to do? As the need for more sustainable ways of living becomes more documented, it is clear that education must focus on environmental issues and build 
competence among students so that future citizens can contribute to reducing the human degradation of the natural environment. Hence, teacher education must train student teachers to have the ability to teach in ways that value sustainability and promote environmentally sound ways of living. The question about sustainability is mostly addressed in discussions about school curriculums, not teacher education curriculums, but there is growing literature on "Teacher education for sustainability" [15-22].

Through a synthesis of the literature on sustainability in teacher education, Evans et al. found different ways in which this concept is embedded [18]. There are also several studies on how education for sustainability is integrated in different teacher education programmes [19-22]. However, we do not know to what extent teacher education programmes actually prepare their students to teach about sustainability and how to counteract environmental destruction and global warming.

There has been a strong call for teacher education to enhance professional competencies among student teachers [23]. Parallel with this call and with the move to focus on self-efficacy, there are several studies on teacher professionalism that try to measure the different dimensions of how teacher education programmes contribute to teacher professionalism [24,25]. Darling-Hammond defines five dimensions of teacher professionalism [24]:

1. Design of curriculum and instruction

2. Support for diverse learners

3. Use of assessment to guide learning

4. Creation of a productive classroom

5. Development of teacher professionalism

These dimensions are in line with the California Standards for the Teaching Profession. The professional aspect of being able, as educators, to work for sustainable development is lacking among these dimensions, as well as in other studies that try to define different aspects of teacher professionalism [25]. Typically, the OECD report on how to support teacher professionalism does not discuss teaching for sustainability. Hence, we do not know to what extent the ability to teach for sustainability is regarded as a dimension of teacher professionalism.

The PROTEUS project, which was founded by the EU Erasmus+ programme, had a goal to investigate how teacher education programmes could strengthen new professionalism. This professionalism was defined more widely than traditional definitions and included the ability to teach in a way the values sustainability and promotes environmentally sound ways of living. Data was gathered from student teachers in teacher education programmes of the seven partners in the PROTEUS project. With this data, we are able to elaborate on what sort of professionalism these teacher education programmes promote and to what extent the questions about ability to educate for sustainable development is present in these programmes.

\section{Method}

A questionnaire on what was defined as new teacher professionalism was developed within the PROTEUS project through a three-step procedure.

First, the Darling-Hammon [24] and Solhaug and Dahl [25] studies and the curriculums of the different programs were discussed and a new list of items was developed. This list was discussed with groups of student teachers and teacher educators in each of the partner institutions. The results of these discussions were then analysed and a final 21-item questionnaire for new teacher professionalism was created. The items cover what teachers today and in the near future should be able to do, and included the following.

1. Teach the concepts, knowledge and skills of your discipline(s) in ways that enable students to learn

2. Plan, carry out and evaluate lessons

3. Use a variety of assessment approaches (e.g., observation, portfolios, tests, performance tasks and anecdotal records) to determine student strengths, needs and programmes 
4. Relate classroom learning to the real world

5. Help all types of students achieve high academic standards

6. Help all types of students in their social and personal development

7. Teach students with different interests and motivations

8. Teach students with different backgrounds

9. Develop students' questioning and discussion skills

10. Embed technology in teaching

11. Take on leadership roles in the class, school or school community

12. Research teaching practices

13. Continuously develop as a teacher

14. Collaborate with colleagues to improve teaching

15. Continuously develop as a teacher in collaboration with other teachers

16. Engage in research and development of practice

17. Learn from others

18. Reflect critically on academic issues

19. Reflect critically on professional-ethical issues

20. Reflect critically on educational policy issues

21. Teach in a way that values sustainability and promotes environmentally sound ways of living

This list overlaps issues in the discussions on teacher professionalism, except for the last item: teach in a way that values sustainability and promotes environmentally sound ways of living.

An online questionnaire was distributed among student teachers in their last year of training in the seven participating programmes. The programmes varied between focusing on primary school and secondary school. The length of the education programmes was also different, as well as whether the programmes addressed specific subject teachers or general education teachers. Thus, the programmes could not be directly compared. However, the questions were about the students' own understanding of how prepared they were to work as teachers. The questions led to answers about how their education was related to their belief of how they would be able to work as professional teachers. What sort of teachers they will work as was of minor importance.

The data were handled in accordance with each country's standards for research ethics. The students were informed about the purpose of the study and that they were free to participate or not. The data were gathered through the programme SelectSurvey, which makes it possible to generate fully anonymous data. No information about the respondents was collected, and IP addresses could not be traced.

The number of respondents from each teacher education programme is listed in Table 1. The response rate varied from 49 to over 90 percent. As the aim was not to compare the different programmes or to find a representative picture of the different programs, but rather to investigate possible dimensions in teacher education and their possible interaction, the rather low response rate in some programmes was of no importance. The data was gathered in the spring semester of 2016.

Table 1. Number of student teachers' responses from the different teacher education programmes.

\begin{tabular}{ccc}
\hline University & Country & Number of Responses \\
\hline Norwegian University of Science and Technology & Norway & 100 \\
Penza State University & Russia & 141 \\
University of Education Weingarten & Germany & 98 \\
University of Edinburgh & Scotland & 17 \\
University College South Denmark & Denmark & 45 \\
University of Oxford & England & 149 \\
Linköping University & Sweden & 28 \\
Total & & 578 \\
\hline
\end{tabular}


All statements about teacher work were guided by the question "How well do you think your teacher education prepares you to ... ?". The response could be given on a five-point Likert scale: "Very poorly prepared" (1), "Poorly prepared" (2), "Neither poorly nor well prepared" (3), "Well prepared" (4) and "Very well prepared" (5).

The data set was analysed with the help of Stata 15.

\section{Results}

There is strong internal consistency between all items in the questionnaire. Cronbach's alpha for all 21 items is 0.928 . This indicates that all the items may contribute to some sort of teacher professionalism and are a measurement of what we defined as new teacher professionalism.

Item 21 (teach in a way that values sustainability and promotes environmentally sound ways of living) has the weakest contribution to the reliability of a measurement based on all the items. Removing this item increases Cronbach's alpha to 0.940 .

Item 21 also differs when comparing the single item scores of all values. While the mean for all other items ranges from 3.53 to 4.11 , the mean score for item 21 is 3.04 . Item 21 also has the strongest variance of all the others, with a standard deviation of 1.13. None of the others have a standard deviation above 1.0.

One-way ANOVA shows significant differences among the students from the different institutions on all items. Item 21 also differs in this respect from all other items, as the difference among institutions explains 45 percent of the variance of the item. For all other items, the contribution is less than 25 percent.

A principle component analysis of all 21 items was used to see if a pattern structure could be established. The analysis was carried out with a component rotation (Oblimin with Kaiser Normalisation), showing four principal components (with an eigenvalue above 1). These four components contributed to 62.3 percent of the total variance of a sum score of all the items. Table 2 shows the pattern matrix of the analysis. Only items with loadings higher/lower than $0.65 /-0.65$ are shown in the table.

Table 2. Component pattern matrix (only loadings higher/lower than $0.65 /-0.65$ are shown).

\begin{tabular}{|c|c|c|c|c|}
\hline Item & 1 & 2 & 3 & 4 \\
\hline $\begin{array}{l}\text { Use a variety of assessment approaches (e.g., observation, portfolios, tests, } \\
\text { performance tasks and anecdotal records) to determine student strengths, } \\
\text { needs and programmes }\end{array}$ & 0.77 & & & \\
\hline Help all types of students achieve high academic standards & 0.73 & & & \\
\hline Help all types of students in their social and personal development & 0.84 & & & \\
\hline Teach students with different interests and motivations & 0.79 & & & \\
\hline Teach students with different backgrounds & 0.85 & & & \\
\hline Develop students' questioning and discussion skills & 0.69 & & & \\
\hline Continuously develop as a teacher & & & -0.77 & \\
\hline Collaborate with colleagues to improve teaching & & & -0.94 & \\
\hline Continuously develop as a teacher in collaboration with other teachers & & & -0.88 & \\
\hline Learn from others & & & -0.70 & \\
\hline Reflect critically on academic issues & & 0.81 & & \\
\hline Reflect critically on professional-ethical issues & & 0.84 & & \\
\hline Reflect critically on educational policy issues & & 0.74 & & \\
\hline $\begin{array}{l}\text { Teach in a way that values sustainability and promotes environmentally sound } \\
\text { ways of living }\end{array}$ & & & & 0.87 \\
\hline
\end{tabular}

Four indexes were made based on the items contributing to the different components. Only items with strong loadings were used for the different indexes. The indexes could be named the following.

Index 1: Teach in ways that meet the differences among pupils

Index 2: Use a critical approach

Index 3: Develop as a teacher 
Index 4: Teach for a sustainable society

The reliability of the indexes for the different components is shown in Table 3. As component 4 has one only one item with a strong loading, the reliability of the component could not be tested.

Table 3. Reliability of the different component indexes.

\begin{tabular}{cc}
\hline Index & Cronbach's Alpha \\
\hline Index 1: Teach in ways that meet the differences among pupils & 0.89 \\
Index 2: Use a critical approach & 0.81 \\
Index 3: Develop as a teacher & 0.89 \\
Index 4: Teach for a sustainable society * & \\
\hline
\end{tabular}

*. Only one item. Reliability could not be tested.

The three indexes that could be tested show good reliability. The pattern structure of these three items was tested through a confirmatory factor analysis. The analysis shows a good fit of the model [26], with a root mean squared error of approximation of 0.085 , a comparative fit index of 0.946 and a Tucker-Lewis index of 0.930 .

Table 4 shows the mean value and standard deviation of the indexes for the components on a five-step scale and Table 5 shows the correlation values for the components.

Table 4. Mean value and standard deviation of the indexes.

\begin{tabular}{ccc}
\hline Principal Components & Mean & SD \\
\hline Index 1: Teach in ways that meet the differences among pupils & 3.68 & 0.62 \\
Index 2: Use a critical approach & 3.84 & 0.71 \\
Index 3: Develop as a teacher & 3.97 & 0.74 \\
Index 4: Teach for a sustainable society & 3.07 & 1.13 \\
\hline
\end{tabular}

Table 5. Correlation table for the four principal components.

\begin{tabular}{|c|c|c|c|c|}
\hline Principal Components & 1 & 2 & 3 & 4 \\
\hline Index 1: Teach in ways that meet the differences among pupils & 1 & $0.459 * *$ & $-0.625^{* *}$ & $-0.116^{*}$ \\
\hline Index 2: Use a critical approach & $0.459 * *$ & 1 & $-0.517^{* *}$ & -0.033 \\
\hline Index 3: Develop as a teacher & $-0.625^{* *}$ & $-0.517 * *$ & 1 & 0.043 \\
\hline Index 4: Teach for a sustainable society & $-0.116^{*}$ & -0.033 & 0.043 & 1 \\
\hline
\end{tabular}

*. Correlation is significant at the 0.05 level (2-tailed). ${ }^{* *}$. Correlation is significant at the 0.01 level (2-tailed).

The correlation matrix for these four components is shown in Table 5.

There is a strong interdependence between three of the components for teacher professionalism. These dimensions are strongly integrated. The component "trained to teach for a sustainable society" shows almost no integration with the others.

Table 6 shows the mean score index (item 21) for the different teacher education programmes.

Table 6. Mean, standard error and standard deviation on "How well do you think your teacher education prepares you to teach in a way that values sustainability and promotes environmentally sound ways of living?"

\begin{tabular}{ccccc}
\hline Teacher Education Programme At & Country & Mean & SE & SD \\
\hline Norwegian University of Science and Technology & Norway & 2.94 & 0.10 & 0.95 \\
Penza State University & Russia & 1.99 & 0.07 & 0.83 \\
University of Education Weingarten & Germany & 3.30 & 0.09 & 0.89 \\
University of Edinburgh & Scotland & 4.00 & 0.17 & 0.71 \\
University College South Denmark & Denmark & 3.30 & 0.15 & 0.99 \\
University of Oxford & England & 3.66 & 0.08 & 1.00 \\
Linköping University & Sweden & 3.78 & 0.11 \\
\hline
\end{tabular}




\section{Discussion}

The data from seven different teacher education programmes in Europe shows that it is possible to measure how students think their education prepares them to work as teachers along different aspects of teacher professionalism. The data show that students' thoughts about being prepared to work as teachers could be ordered according to four different dimensions: teaching in ways that meet the differences among pupils, having a critical approach as a teacher, developing as a teacher and teaching for a sustainable society. Two of these dimensions overlap with the dimensions Darling-Hammond found among student teachers at Stanford University in California [24]: the ability to support diverse learners and teacher professional development.

One of these dimensions is at odds with the dimensions found in both Darling-Hammond's and Solhaug and Dahl's [24,25] studies: the ability to teach for sustainability. This dimension stands out on the base of only one item. Thus, we could not test its reliability. The item was also at odds with all other items, as the mean score was significantly lower than the score of all other items. The standard deviation was also much larger, mostly due to significant differences in the scores from the students from the different teacher education programmes. This may indicate a low concept validity of the item, and there may be different conceptions of the questions among the students in different countries. However, we can explain some of this variance by external factors. Evans et al. made a search through teacher education programme curriculums and found only Scotland to include sustainability in teacher professional standards [18]. This finding may not be correct, as we know that teaching for sustainability is found in different teacher education curricula in other countries [19,20,22]. However, of the seven programmes in this study, only Edinburgh had a curriculum clearly addressing the need for teachers to teach for a sustainable society. The students in the teacher education programme in Edinburgh gave a significantly higher score on the item than the students from all other programmes. Our data may show traces of this curriculum initiative.

Both nationally and at an EU level there is a drive to raise the quality of teaching and to "revise and strengthen the professional profile of all teaching professions" [27]. Our data indicates that teacher education is following this drive. Students feel prepared to meet the demands of being a professional teacher in that they feel they can cope with the differences among pupils and are thus prepared to work as teacher in schools and classes with large variety among students regarding their abilities and needs. Student teachers also feel they are prepared to be critical of their own practice and reflect on what they are doing, and, in line with the ideas of professionalism drawn from the European commission and OECD, they feel prepared to work collaboratively and to learn and develop themselves as teachers.

The teacher education programmes taking part in PROTEUS did so primarily because of a common interest in strengthening the professional profile of teachers through teacher education. In these programmes the ability to work with education for sustainability is something these student teachers feel themselves less prepared to do; this aspect of professionalism clearly lags behind all other dimensions of professionality we have measured. There is a strong difference among the institutions on how students think about their self-efficacy in teaching for sustainability, indicating that the issue is given different weight in teacher education programmes around Europe. Issues in sustainability are commonly found in the school curricula in most countries, but are generally not a mandatory component in initial teacher education [18]. There are also general claims that teachers do not feel very competent in including sustainability issues in their teaching [22] and that the issue is not sufficiently addressed [28]. Our data support such claims, but also indicates that making the competence to teach for sustainability a clear goal in the curriculum can strengthen this element of teaching, as the students in the programme in Edinburgh have a significantly higher score than all other programmes.

Evans et al. found four different modes in which teacher education embeds sustainability education in their teaching and learning: (1) embedding sustainability education widely across curriculum areas, courses and institutions; (2) through a dedicated core/compulsory subject; (3) through a component of a core/compulsory subject; and (4) through a dedicated elective subject [18]. Our data indicate that the issue of sustainability is hardly integrated in the other dimensions of teacher 
professionality in teacher education. When having teacher education better deal with sustainability and environmental issues, the question of how this should be done arises. Evans et al. could not rank which of the four different ways is most fruitful; neither can our data. But as teacher education in general moves to become more research oriented, and since research competence is seen as important for teachers [29], one way could be, as Kalsoom and Khanam showed, to integrate sustainability into research method courses [30]. There are also ways to integrate sustainability issues in higher education in general [31,32]. For teacher education it seems like the main task is still to have a focus on sustainability issues. In most general accounts of teacher education the issue is lacking [29,33]. Many of these accounts are concerned about how teacher education generates a teacher identity among students. Setting this identity development in the context of education for sustainable development also seems to be lacking [34].

There is a general problem of having newly recruited teachers continue to work as teachers [35]. Altruistic motives and social utility are often seen as motivational factors for teachers [36]. Typically, in finding which factors student teachers identify as most important to teach, environmental issues are lacking. Factors like enhancing social equity and making social contributions are present, but not how to work for a sustainable world [36]. Literature arguing for a sort of call among teachers [37-39] hardly raise the issue of environmental problems. The call for teachers is mainly seen as being devoted to the development of children, not to how these children can work for more sustainable human activities in the future. It appears the literature on teacher profession is still devoted to the classical understanding of the profession, where the aspect of sustainability is lacking $[34,40]$.

There is a discussion about different sorts of professionalism in the literature. Linda Evans speaks about a focus on functionality on the one hand and attitude on the other, and claims that the functional development is more targeted [41]. Martin, Summers and Sjerps-Jones make a division between what they call a technical-rational model for professionality on one side and a creative-interpretive model on the other [16]. The creative-interpretive model would typically have a focus on values and ethics.

On the basis of our findings, we think such a division of teacher education is not fruitful. We argue for a more integrative model, as the question of sustainability is not just about values and ethics; it is about content, pedagogy and didactics as well. The literature on teacher professionalism and teacher education has, however, primarily been interested in how to make a bridge between theory and practice in teacher education [42]. There are now many studies that show how different teacher education programmes make such an integration [19-22,43]. Our data shows there is still a job to do to make education for sustainability a standard element in teacher professionalism.

\section{Conclusions}

The seven teacher education programmes in our study show that teacher education programmes around Europe are successful in training student teachers for a new sort of professionalism, and student teachers feel well prepared to work as qualified teachers. However, the students in these programmes generally feel less prepared to work as teachers with questions about sustainability and sustainable ways of living. These programmes typically put less focus on training student teachers to be able to teach about sustainable development. Problematically, the question of education for sustainability is not integrated into other aspects of professionalism in teacher education. There are strong indications that these findings could make a more general claim and that neither teacher education nor research on teacher education and teacher identity building have fully addressed education for sustainability as an important and full component of teacher professionalism.

However, views on how teacher education prepares them to educate for sustainability varied strongly among the students from the different teacher programmes. Strong variation was also found among European teachers concerning their awareness of environmental problems [44]. Perhaps cultural and economic traits can explain this variation, both in teacher education programmes and among teachers. Our study does, to some extent, support such a thesis, but we also found that making demands of teacher education curricula to deal with education for sustainability may positively affect 
change. This calls for curriculum studies of teacher education programmes to determine where and to what extent the issues of sustainability have a place.

\section{Limitations}

The instrument developed to measure student teachers' thoughts about how much their teacher education programme prepares them to work as professional teachers has high reliability regarding the classical dimensions of teacher professionalism, such as the ability to continuously develop as a teacher, which has been promoted strongly the last 20 years. We found that the ability to teach for sustainability should be integrated as a dimension of teacher professionalism. However, the reliability of the question measuring students' thoughts on how prepared they feel to teach for sustainability could not be tested. Our study did not measure well the students' thoughts on this issue, and the results should not be interpreted in any absolute sense. Thus, there is still a question of how to accurately measure how teacher education programmes train student teachers to teach for sustainability and how this competence relates to the other domains of teacher professionalism.

Although the findings of a lack of training to educate for sustainability is supported by other studies, we still do not have enough data to make general claims on to what extent training to teach for a sustainable society is a component in European teacher education programmes and how strongly this aspect of teacher professionalism has become a part of teacher education.

Funding: The data used in this article was produced within the PROTEUS project, financed by the European Commision through the Erasmus +-Programme, Strategic Partnership, project no. 2015-1-NO01-KA203-013255.

Acknowledgments: The questionnaire used in this study was developed within the PROTEUS project. I'll like to thank all those who participated in the project and who took part in the discussions on new teacher professionalism, especially from Linköping University, Per Simfors and Malin Westlund, from University of Oxford, Katharine Burn, Trevor Mutton and Jason Todd, from University College South Denmark, Mette Skovgaard Ernlund, Robert Eskildsen Jepsen, Alexander von Oettingen and Lars Breinholt Søndergaard, from University of Edinburgh, Nicola Carse and Aileen Kennedy, from University of Education Weingarten, Markus Janssen and Thomas Wiedenhorn, from Penza State University Nataliia Pavlova and Olga Surina, from Norwegian University of Science and Technology Peter Gray, Per Ramberg, Lise Vikan Sandvik and Ela Sjølie, from Charlottenlund Upper Secondary School, Nina Hoseth and Arve Johnny Svendsen and from Charlottenlund Lower Secondary School, Rune Flatås and Bjørn Ivar Midjo.

Conflicts of Interest: The author declares no conflict of interest.

\section{References}

1. Blömeke, S.; Buchholtz, N.; Suhl, U.; Kaiser, G. Resolving the chicken-or-egg causality dilemma: The longitudinal interplay of teacher knowledge and teacher beliefs. Teach. Teach. Educ. 2014, 37, 130-139. [CrossRef]

2. Bandura, A. Self-Efficacy: The Exercise of Control; Freeman: New York, NY, USA, 1997.

3. Bandura, A. Social Foundations of thought and Action: A Social Cognitive Theory; Prentice-Hall, Inc.: Englewood Cliffs, NJ, USA, 1986.

4. Skaalvik, E.M.; Skaalvik, S. Dimensions of teacher self-efficacy and relations with strain factors, perceived collective teacher efficacy, and teacher burnout. J. Educ. Psychol. 2007, 99, 611. [CrossRef]

5. Goddard, R.D.; Hoy, W.K.; Hoy, A.W. Collective Teacher Efficacy: Its Meaning, Measure, and Impact on Student Achievement. Am. Educ. Res. J. 2000, 37, 479-507. [CrossRef]

6. Marsh, H.W.; Martin, A.J. Academic self-concept and academic achievement: Relations and causal ordering. Br. J. Educ. Psychol. 2011, 81, 59-77. [CrossRef] [PubMed]

7. Judge, T.A.; Erez, A.; Bono, J.E.; Thoresen, C.J. Are measures of self-esteem, neuroticism, locus of control, and generalized self-efficacy indicators of a common core construct? J. Pers. Soc. Psychol. 2002, 83, 693-710. [CrossRef]

8. Dacre Pool, L.; Qualter, P. The dimensional structure of the emotional self-efficacy scale (ESES). Aust. J. Psychol. 2012, 64, 147-154. [CrossRef]

9. Morony, S.; Kleitman, S.; Lee, Y.P.; Stankov, L. Predicting achievement: Confidence vs self-efficacy, anxiety, and self-concept in Confucian and European countries. Int. J. Educ. Res. 2013, 58, 79-96. [CrossRef] 
10. Di Giunta, L.; Alessandri, G.; Gerbino, M.; Luengo Kanacri, P.; Zuffiano, A.; Caprara, G.V. The determinants of scholastic achievement: The contribution of personality traits, self-esteem, and academic self-efficacy. Learn. Individ. Differ. 2013, 27, 102-108. [CrossRef]

11. Moriarty, B.; Douglas, G.; Punch, K.; Hattie, J. The importance of self-efficacy as a mediating variable between learning environments and achievement. Br. J. Educ. Psychol. 1995, 65, 73-84. [CrossRef] [PubMed]

12. Kirk, B.A.; Schutte, N.S.; Hine, D.W. Development and preliminary validation of an emotional self-efficacy scale. Pers. Individ. Differ. 2008, 45, 432-436. [CrossRef]

13. OECD. TALIS 2013 Results. An International Perspective on Teaching and Learning; OECD Publishing: Paris, France, 2014.

14. OECD. TALIS 2013 Technical Report; OECD: Paris, France, 2014.

15. Fien, J.; Maclean, R. Teacher Education for Sustainability. In Education for a Sustainable Future: A Paradigm of Hope for the 21st Century; Wheeler, K.A., Bijur, A.P., Eds.; Springer: Boston, MA, USA, 2000; pp. 91-111.

16. Martin, K.; Summers, D.; Sjerps-Jones, H. Sustainability and teacher education. J. Further High. Educ. 2007, 31, 351-362. [CrossRef]

17. Summers, D.; Cutting, R. Education for Sustainable Development in Further Education: Embedding Sustainability into Teaching, Learning and the Curriculum; Palgrave Macmillan UK: London, UK, 2016.

18. Evans, N.; Stevenson, R.B.; Lasen, M.; Ferreira, J.-A.; Davis, J. Approaches to embedding sustainability in teacher education: A synthesis of the literature. Teach. Teach. Educ. 2017, 63, 405-417. [CrossRef]

19. Burmeister, M.; Schmidt-Jacob, S.; Eilks, I. German chemistry teachers' understanding of sustainability and education for sustainable development-An interview case study. Chem. Educ. Res. Pract. 2013, 14, 169-176. [CrossRef]

20. Gjøtterud, S.M.; Sinnes, A.T. Science teacher education for sustainable development: A case study of a residential field course in a Norwegian pre-service teacher education programme AU-Jegstad, Kirsti Marie. J. Adv. Educ. Outdoor Learn. 2018, 18, 99-114.

21. Corney, G.; Reid, A. Student teachers' learning about subject matter and pedagogy in education for sustainable development. Environ. Educ. Res. 2007, 13, 33-54. [CrossRef]

22. Uitto, A.; Saloranta, S. Subject Teachers as Educators for Sustainability: A Survey Study. Educ. Sci. $2017,7,8$. [CrossRef]

23. European Commission. Supporting Teacher Competence Development for Better Learning Outcomes. Available online: http:/ / ec.europa.eu/education/policy/school/doc/teachercomp_en.pdf (accessed on 14 October 2015).

24. Darling-Hammond, L. Assessing teacher education: The usefulness of multiple measures for assessing program outcomes. J. Teach. Educ. 2006, 57, 120-138. [CrossRef]

25. Solhaug, T.; Dahl, T. Assessing the Outcome of Teacher Education Programs in Norway: An Analysis and Discussion of the Factor Structure in Domains of Teacher Practicum for Student Teachers at Three Norwegian Universities. Creat. Educ. 2016, 7, 1518-1536. [CrossRef]

26. Kline, R.B. Principles and Practice of Structural Equation Modeling, 3rd ed.; Guilford publications: New York, NY, USA, 2011.

27. European Commission. Rethinking Education: Investing in Skills for Better Socio-Economic Outcomes; European Commission: Strasbourgh, France, 2012.

28. Krofta, H.; Buchholz, M.; Nordmeier, V.; Schulte, C. Förderung von BNE-Kompetenzen bei Lehrkräften durch zyklische Unterrichtsentwicklung im Lehr-Lern-Labor. In Befähigung zu gesellschaftlicher Teilhabe: Beiträge der fachdidaktischen Forschung; Menthe, J., Höttecke, D., Zabka, T., Hammann, M., Rothgangel, M., Eds.; Waxmann: Münster, Germany, 2016; pp. 185-204.

29. Menter, I.; Peters, M.A.; Cowien, B. A Companion to Research in Teacher Education. In A Companion to Research in Teacher Education; Peters, M.A., Cowie, B., Menter, I., Eds.; Springer: Singapore, 2017.

30. Kalsoom, Q.; Khanam, A. Inquiry into sustainability issues by preservice teachers: A pedagogy to enhance sustainability consciousness. J. Clean. Prod. 2017, 164, 1301-1311. [CrossRef]

31. Biasutti, M.; De Baz, T.; Alshawa, H. Assessing the Infusion of Sustainability Principles into University Curricula. J. Teach. Educ. Sustain. 2016, 18, 21-40. [CrossRef]

32. Biasutti, M.; Makrakis, V.; Concina, E.; Frate, S. Educating academic staff to reorient curricula in ESD. Int. J. Sustain. High. Educ. 2018, 19, 179-196. [CrossRef]

33. Clandinin, D.J.; Husu, J. The SAGE Handbook of Research on Teacher Education; Sage: London, UK, 2017. 
34. Raus, R. Student Teacher Ecological Self in the Context of Education for Sustainable Development: A Longitudinal Case Study. J. Educ. Sustain. Dev. 2017, 11, 123-140. [CrossRef]

35. Smith, K.; Ulvik, M. Leaving teaching: Lack of resilience or sign of agency? Teach. Teach. 2017, 23, 928-945. [CrossRef]

36. Watt, H.M.G.; Richardson, P.W. Motivational Factors Influencing Teaching as a Career Choice: Development and Validation of the FIT-Choice Scale. J. Exp. Educ. 2007, 75, 167-202. [CrossRef]

37. Korthagen, F.A.J. In search of the essence of a good teacher: Towards a more holistic approach in teacher education. Teach. Teach. Educ. 2004, 20, 77-97. [CrossRef]

38. Biesta, G. The Beautiful Risk of Education; Routledge: London, UK, 2016.

39. Biesta, G. Education, Measurement and the Professions: Reclaiming a Space for Democratic Professionality in Education. Educ. Philos. Theory 2017, 49, 315-330. [CrossRef]

40. Menter, I.; Hulme, M.; Elliot, D.; Lewin, J. Literature Review on Teacher Education in the 21st Century; Education Analytical Services, Schools Research, Scottish Government: Edinburgh, France, 2010.

41. Evans, L. Professionalism, professionality and the development of education professionals. Br. J. Educ. Stud. 2008, 56, 20-38. [CrossRef]

42. Korthagen, F.A.J. How teacher education can make a difference. J. Educ. Teach. 2010, 36, 407-423. [CrossRef]

43. Hugerat, M.; Mamlok-Naaman, R.; Eilks, I.; Hofstein, A. Professional Development of Chemistry Teachers for Relevant Chemistry Education. In Relevant Chemistry Education: From Theory to Practice; Eilks, I., Hofstein, A., Eds.; Sense Publishers: Rotterdam, The Netherlands, 2015; pp. 369-386. [CrossRef]

44. Anđić, D.; Vorkapić, S.T. Teacher Education for Sustainability: The Awareness and Responsibility for Sustainability Problems. J. Teach. Educ. Sustain. 2017, 19, 121. [CrossRef]

(C) 2019 by the author. Licensee MDPI, Basel, Switzerland. This article is an open access article distributed under the terms and conditions of the Creative Commons Attribution (CC BY) license (http:/ / creativecommons.org/licenses/by/4.0/). 